\title{
RISK FACTORS OF COVID-19 TRANSMISSION BETWEEN HOSPITAL EMPLOYEES
}

\author{
Siti Ulfah"), Cicilya Candi²), Ede Surya Darmawan²) \\ 1)Masters Program in Hospital Administration, \\ Faculty of Public Health, Universitas Indonesia \\ 2)Faculty of Public Health, Universitas Indonesia
}

\begin{abstract}
Background: Coronavirus disease 2019 (Covid-19) in healthcare workers at hospital has caused concern because of the higher rates of infection from patients. The aimed of the study was to investigate the risk factors of covid-19 transmission between hospital employees.

Subject and Method: This was a qualitative study conducted from August to September 2020. A total of 19 confirmed Covid-19 cases were selected for this study. The data were collected by in-depth interview analyzed descriptively.

Result: From 19 confirmed Covid-19 cases, 15 of it were medical staff (78.95\%) and the rest were non medical staff (21.05\%). The risk factors of transmission were direct contact with confirmed Covid-19 patient and neglected health protocol.

Conclusion: The risk of Covid-19 transmission among hospital employees increases with a direct contact with patients and the neglection of health protocol.
\end{abstract}

Keywords: Covid-19 transmission, hospital employees

\section{Correspondence:}

Siti Ulfah. Masters Program in Hospital Administration, Faculty of Public Health, Universitas Indonesia. Email: sitiulfah111@gmail.com. Mobile: (021) 7864975.

\section{BACKGROUND}

The COVID-19 pandemic is a severe problem for health, and to date, cases continue to increase in several countries. As of 19 September 2020, there were 30,737,361 positive cases of COVID-19, and 957,243 deaths (CFR 3.1\%), which came from 213 countries in the world (Worldometer, 2020). Meanwhile, there were 240,687 positive cases in Indonesia, starting from the first case on 2 March 2020, and the death rate reached 9,448 people (CFR $3.9 \%)$. Cases were recorded in 34 provinces, 490 districts, and Indonesia (Ministry of Health, 2020).

COVID-19 is an infectious disease caused by SARS-CoV-2 (Severe Acute Respiratory Syndrome Coronavirus 2), its rapid transmission has made WHO designate COVID-19 as a Public Health
Emergency of International Concern (PHEIC) / a Public Health Emergency that is Concerning the World (KKMMD) on 30 January 2020 (WHO and Ministry of Health, 2020).

Transmission of COVID-19 can occur through droplets, direct and indirect contact, and information through contaminated objects or surfaces due to the use of infected people (knowledge of phomites). On 9 July 2020, WHO issued a scientific brief "Transmission of SARS-CoV2: implications for infection prevention precautions", that transmission of COVID19 can also occur through the air (airborne) based on several experimental studies. People can transmit COVID-19 with symptoms or people without symptoms (WHO, 2020).

The $7^{\text {th }}$ International Conference on Public Health Solo, Indonesia, November 18-19, 2020 |30 https://doi.org/10.26911/the7thicph-FP.01.04 
Attention to the transmission of COVID-19, several health protocols are very important for lowering the risk of transmission and breaking the spread chain of COVID-19, such as Physical Distancing, limiting close contact (keep a safe distance of > 1-2m), hand hygiene, such as handwashing with soap, use of masks, coughing/sneezing etiquette, environmental cleaning and sneezing (WHO and Ministry of Health, 2020).

Based on research published in The Lancet at the end of July 2020 entitled "Risk of COVID-19 among front-line healthcare workers and the general community: a prospective cohort study" which discusses the health risks for medical workers caring for COVID-19 patients. From 2,135 190 respondents who took part in the study indicated that medical workers were at three times the risk of contracting COVID-19 than ordinary people. Some of the factors that influence direct contact with COVID-19 patients, availability and use of Personal Protective Equipment (PPE), including repeated use, can increase the risk of contracting COVID-19 to health workers. (Nguyen et al., 2020)

Several actions can reduce the risk of transmission to health workers, including the use of appropriate PPE, compliance with infection prevention measures such as washing hands, maintaining physical distance when in contact with coworkers such as during meetings, eating together and in the office space knowledge of symptoms leading to COVID-19 in health workers followed by immediate screening and evaluation for further action can also reduce transmission to health workers (Bielicki et al., 2020)

RS.X is one of the non-referral hospitals for COVID-19 in the city of Bukittinggi. However, during this pandemic RS.X certainly does not avoid treating patients who have the possibility of being COVID-19 patients, be it outpatient, emergency or inpatient care. RS.X has carried out standard precautions for infection prevention by providing routine PPE inpatient care.

However, in August-September 2020, there were 19 confirmed cases of COVID-19 or as much as $3.84 \%$ of the total employees of RS.X. The increase in COVID19 cases in hospital employees, both health workers and non-health workers, can cause problems in health services at RS.X. All exposed employees need to receive treatment or undergo self-isolation, then tracing is also carried out for close contact which is also likely to increase the number of confirmed cases for other employees. This research was conducted to determine how COVID-19 transmission to employees at RS.X and the factors that increase the risk. So that solutions can be found to prevent and reduce the increase in COVID-19 cases in the RS.X.

\section{SUBJECTS AND METHOD}

\section{Study Design}

This research is a qualitative descriptive study, with the case study method

\section{Population and Sample}

The research sample was 19 employees of RS.X who contracted COVID-19. The data taken is employee data for confirmation of COVID-19 from August to September 2020.

\section{Data analysis}

19 cases of RS.X employees infected with COVID-19, then conducted interviews with related parties regarding the transmission process and factors that increase the risk. The data taken is data on hospital employees' COVID19 confirmation cases. X.

The $7^{\text {th }}$ International Conference on Public Health Solo, Indonesia, November 18-19, 2020 |31 https://doi.org/10.26911/the7thicph-FP.01.04 


\section{RESULTS}

RS.X is one of the non-referral hospitals for COVID-19 in the city of Bukittinggi. However, with the current condition that there is a surge in COVID-19 cases in all regions, of course, RS.X cannot avoid providing services for suspected cases, even confirmation of unknown COVID-19 at the time the patient first entered. The services provided are suitable for outpatient, emergency and inpatient care.

Hospital employees can of course come into contact with patients who have been suspected/suspected of COVID-19 from the start or who were not suspected from the start of treatment because they are categorized as People without Symptoms.

This puts all employees at RS.X at risk of being infected with COVID-19 in the hospital. From the data available from August to 17 September 2020, 19 employees were exposed to COVID-19 or $3.84 \%$ of the total RS.X employees. A significant increase occurred in September 2020, which can be seen in the chart of the distribution of exposed employees' daily cases.

From the graph, it can be seen that in August there were 3 employees infected with COVID-19, and in September there were an additional 16 cases of COVID-19 confirmation.

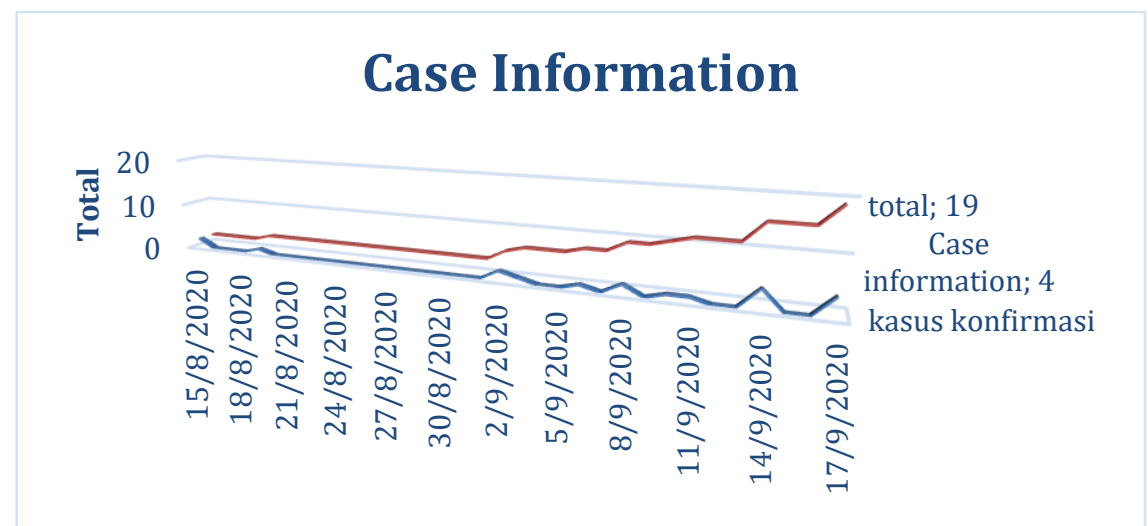

Graph 1. Cases of Confirmation of COVID-19 among RS.X Employees

Table 1. Criteria and Risk Factors COVID-19 on Employee RS.X

\begin{tabular}{|c|c|c|}
\hline Criteria & $\begin{array}{c}\text { Total } \\
(n=19)\end{array}$ & Percentage (\%) \\
\hline \multicolumn{3}{|l|}{ Working Unit } \\
\hline Health Workers & 15 & $78.95 \%$ \\
\hline Non Medicals & 4 & $21.05 \%$ \\
\hline \multicolumn{3}{|l|}{ Points Transmission } \\
\hline Inside the hospital & 16 & $84.21 \%$ \\
\hline Outside the hospital & 3 & $15 \cdot 79 \%$ \\
\hline \multicolumn{3}{|l|}{ Source of transmission } \\
\hline Patients & 6 & $31.59 \%$ \\
\hline Health workers & 9 & $47.36 \%$ \\
\hline Others & 4 & $21.05 \%$ \\
\hline \multicolumn{3}{|l|}{ Symptoms } \\
\hline Without symptoms & 8 & $42.10 \%$ \\
\hline
\end{tabular}




\begin{tabular}{lcc}
\hline Mild & 9 & $47.37 \%$ \\
$\begin{array}{l}\text { Moderate } \\
\text { Risk Factors of Transmission }\end{array}$ & 2 & $10.53 \%$ \\
Lack of discipline in wearing masks & & $73.68 \%$ \\
$\begin{array}{l}\text { Physical distance is not carried out } \\
\text { Disrespect for peer health protocols }\end{array}$ & 14 & $52.63 \%$ \\
$\begin{array}{l}\text { The EPP is not up to standard for confirmatory } \\
\text { cases }\end{array}$ & 10 & $52.63 \%$ \\
\hline
\end{tabular}

Table 2. Factors that increase the risk of COVID-19, solutions and follow-up

\begin{tabular}{|c|c|}
\hline Risk factors & Suggestions and solutions \\
\hline Use of masks & $\begin{array}{l}\text { - According to conditions and work units, socialization and appeal } \\
\text { back to all hospital employees consistently use these masks } \\
\text { whenever and wherever. } \\
\text { - Establishing mask standards for health and non-health workers as } \\
\text { well as when taking aerosol actions }\end{array}$ \\
\hline $\begin{array}{l}\text { Maintain } \\
\text { distance }\end{array}$ & $\begin{array}{l}\text { - The socialization of the importance of physical distancing }>1 \mathrm{~m} \text { in } \\
\text { reducing the risk of transmission } \\
\text { - Increase compliance and remind all hospital rooms to comply with } \\
\text { distance guarding rules such as nurse's room, dining room, meeting } \\
\text { room etc. }\end{array}$ \\
\hline
\end{tabular}

Hand hygiene

Screening

Direct contact with patients
- Socialization and five back of hand hygiene moments in everyday life in a hospital environment.

- Improve compliance with the implementation of handwashing

- Provide and increase the number of hand hygiene facilities in the hospital environment

- Prepare screening forms for all employees, in the form of selfassessment of COVID-19, to capture difficult cases so that follow-up can be carried out, by carrying out further examinations, rapid tests, or conducting swab. Self-assessment can be done periodically in the hospital environment.

- Tighten screening at the entrance to the hospital, outpatient and emergency room, so that employees can raise awareness and use appropriate PPE if there is any suspicion.

- We are preparing a special screening team that can explore the patient's suspicions towards COVID-19 to reduce the conditions for inpatient admission without being detected from the start.

- Socialization of the PPI team regarding standard precautions during the pandemic, always being careful and alert to the possibility of a positive patient with COVID-19. Using PPE properly, removing PPE according to the rules 
- $\quad$ Risk measures for patients must use PPE with a higher level, such as aerosol action using an N95 mask.

Use Of - Making standard guidelines in the hospital environment, for all

Personal

Protective

Equipment (PPE) employees, socialization and advice to comply.

- Socialization of proper PPE fitting and removal.

- Hospital management must also ensure the availability of PPE for employees, especially health workers who are in direct contact with patients.

\section{DISCUSSION}

The PPI unit and the $\mathrm{K}_{3} \mathrm{RS}$ chairman regarding the confirmation case on this RS.X employee from data tracing and interviews with the PPI unit. Several things were found, namely:

1. Most COVID-19 confirmation cases among RS.X employees were health workers, namely $78.95 \%$ consisting of doctors and nurses. The remaining 21.05\% are non-health workers. Health workers are 4 times more likely to be infected than non-health workers in the hospital.

2. The tracing found that the location of transmission in the hospital was higher at 84.21\% of all confirmed cases.

3. The largest transmission source in the confirmed cases of RS.X employees was close contact with fellow health workers, namely $47.7 \%$, followed by infections from patients $31.6 \%$ and others $21 \%$. There is a possibility of transmission between employees when gathering at the porter, eating together, or having discussions/meetings where employees are careless and ignore health protocols with the assumption that it is impossible to transmit between friends.

4. Of the 19 confirmed cases, 8 cases were asymptomatic (42.2\%). Mild symptoms such as fever were not too high and came and went, lost smell and taste in 9 patients (47.7\%). Moderate symptoms, fever, cough, anosmia, and shortness of breath in 2 cases (10.5\%) which for continued treatment were referred to a referral hospital for hospitalization.

5. Several factors that can increase the risk of transmission are, non-compliance with masks both within the hospital and outside the hospital from interviews with 14 cases out of 19 cases, not keeping a distance of 10 cases from 19 cases. Travel using public transportation (no physical distancing) 2 cases. Ignoring health protocols because they were in the peer group as many as 10 cases and the use of PPE was not suitable for confirmation cases in 7 cases, in this condition RS.X employees made contact with patients who were initially unknown as confirmation cases, employees had used PPE, but not meets PPE standards for confirmatory cases. It can be concluded that most of the most risk factors for transmission are lack of adherence to health protocols followed by inappropriate use of PPE when in contact with patients.

Based on the discussion above, the increase in cases was quite significant in September 2020, so researchers suggest screening all employees at risk to help break the chain of spreading COVID-19 in the RS.X environment, namely by using the COVID-19 self-assessment form. 19 for hospital employees.

The $7^{\text {th }}$ International Conference on Public Health Solo, Indonesia, November 18-19, 2020 |34 https://doi.org/10.26911/the7thicph-FP.01.04 
However, in this study, it was found that the transmission process among health workers was higher than the transmission due to contact from patients. After analyzing, a lack of compliance with health protocols occurs when health workers gather in the hospital environment, such as at a porter, while eating, or during a meeting, where employee masks are not correctly attached.

The PPI teams socialization ensures all employees K3RSduring the COVID-19 pandemic understand and must undergo existing procedures using PPE as the first bastion in preventing transmission. Monitoring and evaluation are necessary so that hospital employees are protected from the transmission, and the spread of cases can be reduced.

\section{REFERENCES \\ Bielicki A, Duval X, Gobat N, Gossens H, Koopmans M, Tacconelli E (2020). Monitoring Approaches for health-care workers during tehe COVID-19 pandemic.}

Bielicki JA, Duval X, Gobat N, Goossens H, Koopmans M, Tacconelli E, van der Werf S (2020). Monitoring approaches for health-care workers during the COVID-19 pandemic. The Lancet Infectious Diseases, 20(10). https://doi.org/10.1016/S14733099(20)30458-8

Gugus Tugas Percepatan Penanganan COVID-19 (2020). Standar Alat Pelindung Diri (APD) untuk Penanganan COVID-19 di Indonesia.

Gugus Tugas Percepatan Penanganan COVID-19 (2020). Pedoman Penanganan Cepat Medis dan
Kesehatan Masyarakat COVID19 di Indonesia.

Ikatan Dokter Indonesia, Persatuan Dokter Gigi Indonesia (2020). Petunjuk Pencegahan Penularan COVID19 Untuk Petugas Kesehatan Edisi I

Kementrian Kesehatan Indonesia (2020). Pedoman Pencegahan Dan Pengendalian Coronavirus Disease 2019 (Covid-19) revisi 5.

Kementrian Kesehatan Indonesia (2020). Panduan Pencegahan dan Pengendalian Corona Virus Disease 2019 (COVID-19) di tempat Kerja Perkantoran dan Industri dalam

Nguyen LH, Drew DA, Graham MS, Joshi A D, Guo CG, Ma W, Mehta RS et al. (2020). Risk of COVID-19 among front-line health-care workers and the general community: a prospective cohort study. The Lancet. Public health, 5(9), e475-e483. https://doi.org/10$.1016 / \mathrm{S} 24682667(20) 30164-\mathrm{X}$

Wang J, Zhou M, Liu F (2020). Reasons for healthcare workers becoming infected with novel coronavirus disease 2019 (COVID-19) in China. J. Hosp. Infect. 105(1): 100-101. https://doi.org/10.1016/j.jhin.2020.03.002

World Health Organization (2020). Materi Komunikasi Risiko COVID-19 untuk Fasilitas Pelayanan Kesehatan. 1-11.

World Health Organization (2020). Transmission of SARS-CoV-2: implications for infection prevention precautions, Scientific Brief.

World Health Organization (2020). Global surveillance for COVID-19 caused by human infection with COVID-19 virus.

The $7^{\text {th }}$ International Conference on Public Health Solo, Indonesia, November 18-19, 2020 |35 https://doi.org/10.26911/the7thicph-FP.01.04 